\title{
The definition of an Urban Waste Management Plan: the case of Genoa
}

\author{
F. Pirlone \& I. Spadaro \\ DICCA Department of Civil, Chemical and Environmental Engineering, \\ Polytechnic School, Genoa University, Italy
}

\begin{abstract}
The theme of waste is one of the major environmental challenges at the international level, with a significant impact in the strategies to be adopted in urban areas.

Given the importance of the issue, the EU has required Member States to develop Waste Management Plans. Currently in Italy there are few Plans realized at the municipal level, and the existing tools have quite heterogeneous contents.

The paper shows an EU research on the definition of guidelines for the preparation of an Urban Waste Management Plan; a Plan able to reach an integrated waste system, in which the different stages of management are coordinated and integrated in the context of the whole process.

After the definition of the Guidelines, the paper presents a first elaboration for the Municipality of Genoa which involved University, Public Administration and practitioners in the sector. Currently the city doesn't have a dedicated Plan; the waste management is governed by the Regional Waste Management Plan (2014) and by the Urban Waste Prevention Programme (2010). The new Plan proposed for Genoa has important objectives to solve the specific problems of the territory: from the reduction of waste, to a management economically and environmentally sustainable, to valorization of recyclable and recoverable fractions through separate collection, aiming to the green economy until close of the cycle of the waste with the production of compost.

In order to achieve a good level of implementation, following the preparation of the Plan, the participatory processes will play a key role in ensuring the full consent and cooperation between the actors involved and especially with the population that is the main actuator.
\end{abstract}

Keywords: governance, sustainability, Urban Waste Management Plan. 


\section{Waste as a priority at urban level}

The theme of waste is one of the major environmental challenges at the international level, with a significant impact in the strategies to be adopted in urban areas.

Given the importance of the issue, the EU within of Directive 2008/98/CE [1] doesn't establish only the prevention of waste concept but it introduces the obligation for Member States to draw up National Waste Prevention Programme (deadline December 2013 - Art. 29) and a Waste Management Plan (Art. 28).

In this new scenario, each EU Member Country has had to legislate new regulations on waste management (implemented by Italian law with LD n. 205/2010) within the time limit provided for in the EU Directive. In Italy, with Decree of October 7, 2013, the Italian Ministry of Environment and Protection of Land and Sea adopted the National Waste Prevention Programme.

According to the data collected by the Institute for Environmental Protection and Research (ISPRA), the program establishes three targets for prevention to be achieved by 2020 , compared to the values recorded in 2010 . The objectives concern the production of three types of waste linked to the Gross Domestic Product GDP to correlate this data with socio-economic factors of the State. These objectives are: the reduction of 5\% in the production of municipal waste per unit of GDP and the non-hazardous waste and the reduction of $10 \%$ in the production of hazardous waste per unit of GDP. In preparing the program, the Government has considered a set of general measures that can contribute to the success of prevention policies such as: sustainable production, Green Public Procurement, reuse, information and awareness, economic instruments, fiscal and regulation and the promotion of research.

The last municipal solid waste Report (2014), developed by ISPRA, shows that in Italy the production of waste continues to decline reaching around 29.6 million tons in 2013 (nearly 400,000 tons less than in 2012); a reduction of 8.9\% compared with 2010 (reference year for the National Waste Prevention Programme). The economic crisis can be attributed as a factor which had an impact on the further reduction of waste production, but the increase of recycling $(42.3 \%)$ testifies the improvement of a management. The North is the macro area that records the highest percentage of recycling (54.4\%) followed by the Centre to $36.3 \%$ and the South to $28.9 \%$. The weakness remains the disposal in landfills involving yet $37 \%$ of municipal waste.

In accordance with the National Waste Prevention Programme the regions are preparing guidelines aimed at a sustainable waste management at the regional level. The local level is instead lacking as regards the preparation of the Urban Waste Management Plans. Currently in Italy there are few Plans realized at the municipal level, and the existing tools have quite heterogeneous contents (they develop only disposal, others encourage good practices, others treat special waste).

This paper shows an EU research on the definition of guidelines for the preparation of an Urban Waste Management Plan; a Plan able to reach an integrated waste system, in which the different phases of prevention, production, 
collection, transport, recovery, recycling and final disposal, constitute a coordinated and integrated actions in the context of the whole process.

\section{Methodological approach for the definition of guidelines to prepare an Urban Waste Management Plan}

In this paragraph some results of the research carried out at EU level in which DICCA-University of Genoa is a partner are summarized. The EU project is MED-3R "Euro-Mediterranean strategic platform for a suitable waste management" (ENPI CBCMED - December 2012-December 2015, cooperation area: 14 regions partner of the north and south coast of the Mediterranean basin) where 3R means "Recycle waste, Reduce their production and Reemploy to extend the products lifespan".

To define the guide lines to prepare an Urban Waste Management Plan in the Mediterranean basins originally it's developed a cognitive action to analyze the current (EU and of the partner countries) policy on waste, the experiences, the available knowledge resources and the best practices in force. The EU policy is also important for non-European countries, and especially for those Countries that haven't a specific legislation about waste.

The current EU policy on waste, as it is known, is outlined in the context of Waste Framework Directive 2008/98/EC [1], which lays down measures to protect the environment and human health by preventing or reducing the adverse impacts of the generation and management of waste and by reducing overall impacts of resource use and improving the efficiency of such use (Art. 1). This Directive provides for a general framework of waste management requirements and sets the basic waste management definitions for the EU.

The main goal of this Directive is the prevention, all waste management strategies have to seek the prevention towards a sustainable development for a correct environmental and economic management to reduce waste quantities and dangers. The Directive introduces also the concept of waste hierarchy (Art. 4) shall apply as a priority order in waste prevention and management legislation and policy: prevention, preparing for re-use; recycling, other recovery (for example to produce energy) and as last disposal. When applying the waste hierarchy, Member States shall take measures to encourage the options that deliver the best overall environmental outcome. This Directive imposes also the duty for each Country to adopt a National Waste Prevention Programme (Art. 29) and a Waste Management Plans (Art. 28). Those Plans shall, alone or in combination, cover the entire geographical territory of the Member State concerned.

The aim of Waste Prevention Programme is shall set out the waste prevention objectives able to separate the economic development from the environmental exploitation. This Plan shall be integrated either into the provided Waste Management Plans (the waste prevention measures shall be clearly identified) or, as appropriate, into other separate environmental policy programmes. The main purpose of the Waste Management Plans is, instead, to provide an overview of all waste generated (divided by type of waste streams) in the geographical entity 
concerned, as well as the measures to be taken to improve environmentally sound preparing for re-use, recycling, recovery and disposal of waste and an evaluation of how the plan will support the implementation of the objectives and provisions of this Directive.

The methodological approach, proposed to define the guide lines to prepare an Urban Waste Management Plan, is based on the experiences already realized in the Mediterranean basins.

The ENPI CBCMED is financed by the European Union and consequently to define the guide lines the European documents, on this topic, constitute the reference frame. Between the consulted documents an important role is covered by the "Preparing a Waste Management Plan - A methodological guidance note" [2] proposed by the EC following the 2008 Waste Framework Directive. In this context, the European Guidelines are an important starting point to create a tool dedicated to the sustainable waste management, where this instrument contribute to sustainable planning of waste management by promoting the development of programming practices more consistent and adequate in the partner countries of the project (Pirlone and Spadaro [3]). To give value to the different experiences of each involved partners, a state of art form for analyzed the current waste management was proposed. In Table 1 an extract of the form composed, concern the presence or not of a Waste Management Plan in the territory partners, is reported.

Thanks to the exchange and the comparison between the partners and the results coming from the elaboration of the existing card, the reality of each partners concerning waste (legislation, instrument, best practices, actors...) and the pursued strategies was possible to understand. In this context, a common dictionary between the various partners has proved necessary for to clarify the meaning of the different terms that are commonly used in waste management. As regards for the North Mediterranean Countries the Metropolis of Nice, Cote d'Azur has provided a glossary that result an important instrument to create a common language between the partners (Figure 1).

For the South Mediterranean Countries is very interesting the GIZ methodology, used by the Municipality of Sfax (Tunisia) to define a first draft of a possible Waste Management Plan. The city of Sfax decided, in 2013, to initiate the development of a Municipal Waste Management Plan (Plan Communal de Gestion des Dechets - PCGD [5]) with the support of the German Cooperation GIZ. The PCGD is a strategic planning tool for municipal action on cleanliness; it will help the Municipality to define and structure its actions during the next five year. The development of PCGD was led by the town with the assistance of a team of experts from different specialties. For each of the following areas intervention was created a working team: organization and human resource management; technical aspects of waste management; financial aspects and cost calculation; internal and external communication and participation of civil society. The PCGD was prepared following a first diagnosis of the current situation of waste management in the municipality. The diagnosis and planning phases were done in a participatory process involving all communal services, regional structures and Authorities and civil society. This report presents, in a 
Table 1: Existing card for evaluate the state of art of waste management.

\section{EXISTING CARD - WASTE MANAGEMENT PLAN}

\section{IF EXISTS SPECIFY/DESCRIBE:}

- $\quad$ Level (municipal, provincial, regional);

- The relevant legislation and responsible actors on the waste;

- The main active best practices on waste in your area (e.g. waste collection door to door, bins, returnable...);

- Actions concerning prevention (waste not produced, e.g. dispenser, bulk products);

- Actions specifically for the historical center fabric;

- The relationship between your waste management plan and your government land plans;

- How the population is involved (awareness-raising, information, participation in the stages of preparation of the plan);

- Actions aimed at a training approach/cultural (museums specific on the issue of waste, courses in schools, exhibitions).

\section{IF NOT EXISTS SPECIFY/DESCRIBE:}

- Other reduction Plans or implementation Plans for the management of waste (e.g. municipal solid waste disposal Plans, special, industrial...);

- The relationship between your waste management Plan and your government land Plans;

- The relevant legislation and responsible actors on the waste;

- Policies implemented in today for waste management in your territories;

- Data on the production of municipal waste (quantity of waste generated), on the production of those packaging and the industrial ones;

- How tourism affects the production of waste;

- As the presence of industries in your territories affect the production of waste and its dangerousness;

- How is the disposal of waste (e.g. landfill, recycling...);

- If there is a separate collection (indicate the type of waste). Steps/processes to treat it. Objectives achieved (e.g. indicate percentages);

- The main active best practices on waste in your area (e.g. waste collection door to door, bins, returnable...);

- Actions concerning prevention (waste not produced, e.g. dispenser bulk products...);

- $\quad$ Actions specifically for the biodegradable waste (compost);

- Actions specifically for the historical center fabric;

- How the population is involved (awareness-raising, information, participation in the stages of preparation of the Plan);

- Actions aimed at a training approach/cultural (museums specific on the issue of waste, courses in schools, exhibitions).

first part, the project and strategic vision on waste management of the town of Sfax. The document is divided in four components: technical management of waste, organization and management of human resources, internal and external communications and financial management and cost control. Each component includes the following chapters: synthesis of diagnosis, presentation of strategic objectives and areas of intervention, records of shares. In the last chapter, the 


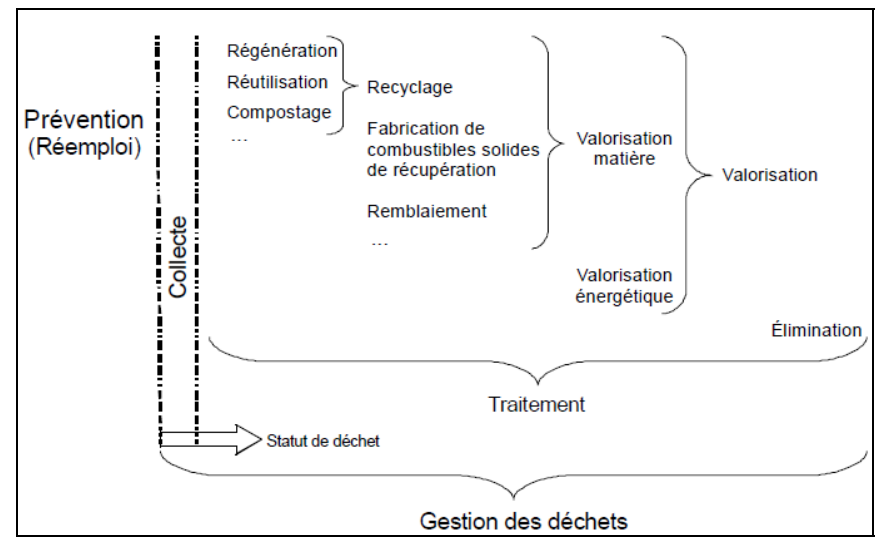

Figure 1: Glossary provided by Metropolis of Nice, Cote d'Azur [4].

shares will be summarized in a program of actions and planned in time. Financing of the tracks will be eventually proposed.

In Table 2 a chart that summarizes the contents present on the PCGD of Sfax is reported.

Table 2: Giz methodology.

\begin{tabular}{|c|c|}
\hline \multirow{4}{*}{ 1. PRE-DEVELOPMENT OF PCGD } & Workshop 1: Launch \\
\hline & Steering committee \\
\hline & Work group \\
\hline & Launch of PCGD \\
\hline \multirow{4}{*}{ 2. DIAGNOSIS OF THE SITUATION } & Collection of information \\
\hline & Strengths/weaknesses \\
\hline & Analysis/evaluation/recommendations \\
\hline & Writing of the diagnostic and summary report \\
\hline \multirow{5}{*}{ 3. DEVELOPMENT OF PCGD } & Workshop 2: Planning/programming \\
\hline & Strategic directions/programming \\
\hline & Actions relevant to remember \\
\hline & Drafting of PCGD \\
\hline & Workshop 3: Consultation/validation \\
\hline \multirow{2}{*}{ 4. IMPLEMENTATION OF PCGD } & Implementation of selected measures \\
\hline & Implementation/execution \\
\hline \multirow{2}{*}{ 5. EVALUATION OF PCGD } & Measure \\
\hline & Analyze \\
\hline
\end{tabular}


The references to define the guide lines in the co-operation territories are: the document Preparing a Waste Management Plan at the European level, the GIZ guide lines and the database created with the information collected with the existing card.

From this information, Genoese partners have prepared a preliminary drafting of guidelines for the preparation of Urban Waste Management Plan where the main elements of each instruments are reported. This schematization has been shared with other partners of the project to define a common and participated support instrument to write this Plan in the cooperation territory.

The chapters of the document may be constituted by 5 fundamental phases. These phases are: 1 . background; 2 . diagnostic of the state of art: status quo and analyzes; 3. planning part; 4. plan application and monitoring; 5. Awareness/ participation.

In the next chapter is shown the Waste Management Plan of Municipality of Genoa, as a first application of guidelines defined in the project.

\section{Waste Management Plan of Genoa as an example for the urban level}

For the preparation of the Waste Management Plan of the Municipality of Genoa [6] University, Public Administration and practitioners in the sector of waste have been involved. Currently the city doesn't have a dedicated Plan; the waste management is governed by the Regional Waste Management Plan (2014) and by the Municipal Waste Prevention Programme (2010). The new Plan proposed for Genoa has important objectives to solve the specific problems of the territory: from the reduction of waste, to a management economically and environmentally sustainable, to valorization of recyclable and recoverable fractions through separate collection, aiming to the green economy until close of the cycle of the waste with the production of compost.

In the first part is present the policy and legislation at the European and Italian level with specific attention to the case of the Liguria Region; area in which this Plan must be implemented. The Steering Committee is also established between the institutions and the practitioners above mentioned and the participatory processes (public meetings, participatory tables and local forums...) who are intend to pursue are identified.

The Plan, in the second part (diagnostics), analyzes the status quo on waste in the Municipality of Genoa. Actually waste management in the Municipality of Genoa is curate by Amiu (Multiservice Urban Hygiene Company). The collection of waste (differentiated and not) takes place through road containers accessible to all, with the exception of historical center where, for the delivery of the waste, special premises called eco-point were organized. Experimental collection services are also being developed in some areas of the city among which: the door to door system, the organic waste collection, systems that use custom keys for the quantification of the waste, the collection direct in ecological islands of bulky waste with a discount on the waste taxes. The collection of waste is performed on average expecting one emptying of bins per day. 
The treatment of the waste depends on the type of waste product.

Paper, cardboard and multi-material are conferred at the plant in Sardorella Street (Bolzaneto). This plant is equipped with advanced machinery capable to separate, treat and reduce in compressed bales, easily transportable, packaging in: plastic, aluminum, steel, paper, cardboard and tetrapak.

The organic waste, at the time, except some examples related to pilot project in the hinterland of Genoa, is awarded in a neighboring province.

The disposal of undifferentiated waste, finally, is conferred at the Scarpino landfill (Sestri Ponente); it is now in uncomfortable conditions and upcoming closure. Today the total waste managed is about $325.69 \mathrm{kt} /$ year, equivalent to $539.22 \mathrm{~kg} /$ to inhabitant. Figure 2 shows a graph relating to trend (from 2007 to 2013) of unsorted and separated waste production in Genoa.

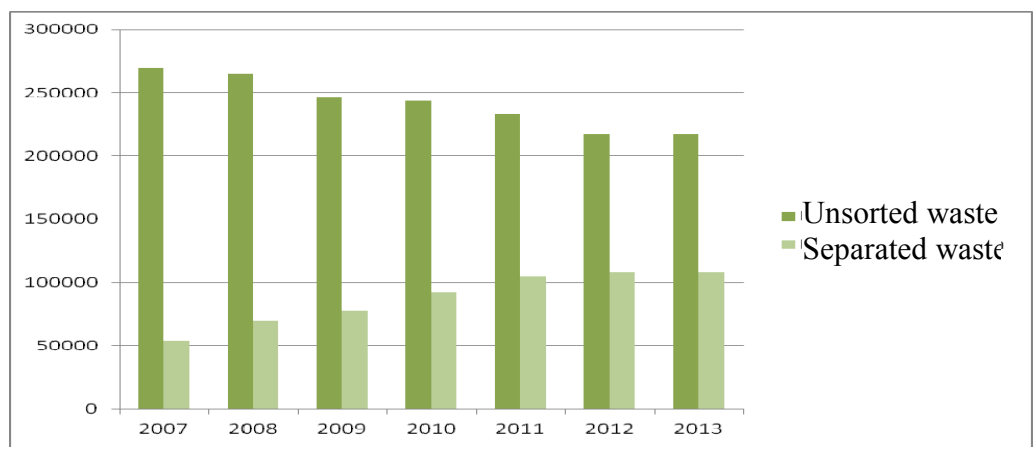

Figure 2: Unsorted and separate waste: trend of production (2007-2013) (Amiu).

After analysis of the status quo a SWOT analysis was made (Table 3) in order to highlight Strengths, Weaknesses, Opportunities and Threats of the Genoa area in relation to the issue of waste.

The most critical problems that characterize the town of Genoa are a high level of waste generation per capita also determined by tourist flows, percentage of average level of separate collection due to the lack of organic waste collection, high operating costs and almost exclusive use of landfills. The priorities indicated by the Plan aim to overcome these problems and, thus, to intercept and calculate the waste produced by tourism, to integrate the separate collection systems with the inclusion of organic waste collection points and the preparation of treatment centers waste other than landfill.

The objectives to be pursued in the Plan (third phase of planning) were identified starting from the problems emerged from the SWOT analysis. They can be summarized as: to promote and develop prevention; to increase recycling to $65 \%$ (as required by EU legislation); to recover $50 \%$ of the waste produced in 2020 (as required by EU); to set up a new bio-digestion plant; to achieve the autonomy in the management of undifferentiated waste (residual) through new plants. For every objective the actions to be taken and monitor over time have been defined (Table 4). 
Table 3: SWOT analysis on waste to the Municipality of Genoa.

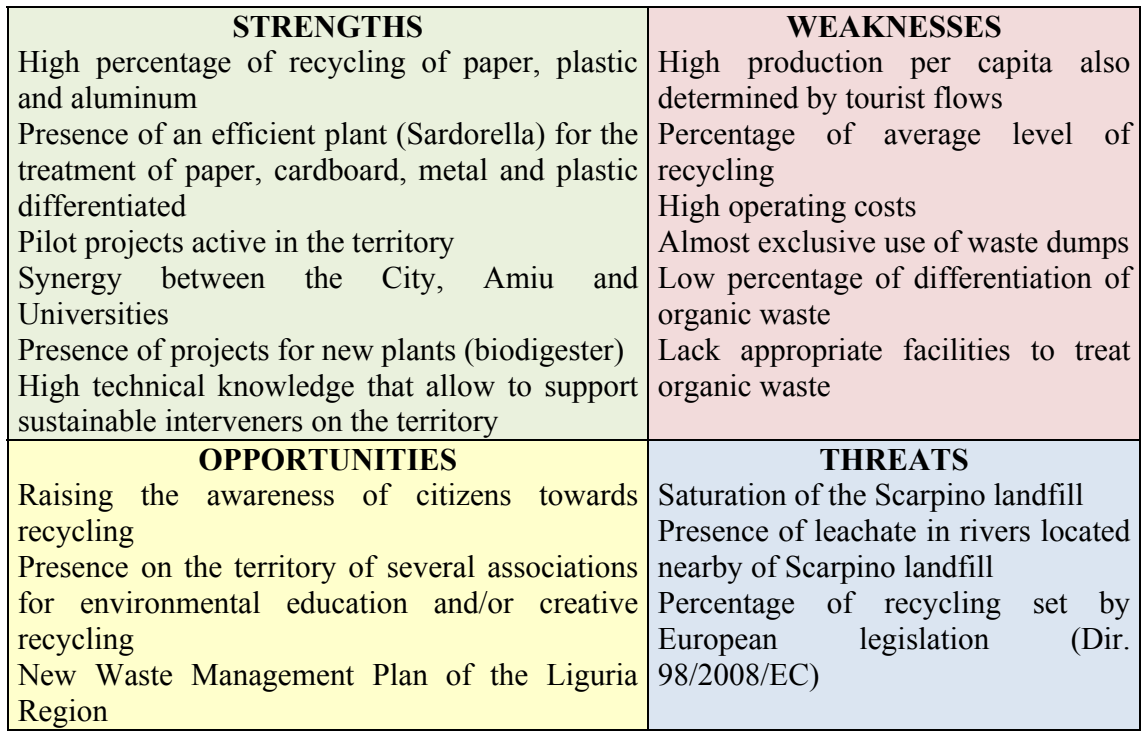

Table 4: Objectives and actions of Urban Waste Management Plan.

\begin{tabular}{|c|c|}
\hline Objectives of the plan & Actions \\
\hline \multirow{4}{*}{$\begin{array}{l}\text { OBJECTIVE } 1 \\
\text { To encourage and develop } \\
\text { prevention }\end{array}$} & $\begin{array}{l}\text { Action I: Promoting the dissemination of Green } \\
\text { Public Procurement }\end{array}$ \\
\hline & Action II: Development of the domestic composting \\
\hline & $\begin{array}{l}\text { Action III: Actions for the reduction of specific types } \\
\text { of waste (e.g. agreements for reuse of food) and } \\
\text { support to activities and processes oriented to a } \\
\text { lower production of packaging waste products }\end{array}$ \\
\hline & $\begin{array}{l}\text { Action IV: Initiatives for the dissemination of the } \\
\text { prevention culture }\end{array}$ \\
\hline \multirow{4}{*}{$\begin{array}{l}\text { OBJECTIVE } 2 \\
\text { Target of } 65 \% \text { of the separate } \\
\text { collection }\end{array}$} & Action I: Strengthening of separate collection \\
\hline & Action II: Strengthening of ecological islands \\
\hline & Action III: Action to raise awareness of plastic waste \\
\hline & Action IV: Strengthening of organic waste collection \\
\hline $\begin{array}{l}\text { OBJECTIVE } 3 \\
\text { Target of } 50 \% \text { of the waste } \\
\text { recovery to } 2020\end{array}$ & $\begin{array}{l}\text { Action I: Increasing at least } 50 \% \text {, in terms of weight, } \\
\text { the preparing for reuse/recovery and recycling of } \\
\text { household waste (e.g. incentives for the purchase of } \\
\text { recycled/recovered items) }\end{array}$ \\
\hline $\begin{array}{c}\text { OBJECTIVE } 4 \\
\text { To recover with other } \\
\text { techniques/technologies }\end{array}$ & Action I: Preparation of a bio-digestion plant \\
\hline \multirow{3}{*}{$\begin{array}{c}\text { OBJECTIVE } 5 \\
\text { To achieve the autonomy in the } \\
\text { undifferentiated waste } \\
\text { management }\end{array}$} & $\begin{array}{l}\text { Action I: Development of “wet/dry" separation } \\
\text { plants }\end{array}$ \\
\hline & Action II: Recovery "dry fraction" \\
\hline & Action III: Adaptations to the Scarpino facility \\
\hline
\end{tabular}


For example, developing the waste separate collection allows the transition from a model of "linear economy" to a model of "circular economy" and it is a key element for a virtuous management of waste, which enables the economic enhancement of waste, in addition to the creation of new jobs and the drastic reduction of unsorted waste to landfills. This Plan involves placing at least one bin for each type of waste material (paper, plastic/metal, glass and organic) in all places of collection, this to entice a citizens to make the separate collection, thereby increasing the percentages of this value. Another action planned is the placement of at least one ecological island for each of the nine districts of Genoa. Awareness actions to the population on the separate collection are also important to forecast. Specifically for the plastic waste the Municipality of Genoa, in collaboration with Amiu and University of Genoa, have engaged in a series of specific actions. In reference to Plastic Waste year (2015) will be organized: laboratories, workshops and seminars thanks to associations of Palazzo Verde (Centre for information and education to energy saving, environment sustainability and waste reduction of the Municipality of Genoa); calls for young artists for creative recycling of plastic and visits for all citizens at the Sardorella center of separation of waste.

Finally, in the Plan, a specific action for strengthening the separate collection of organic waste has been considered (Table 5). The result of the organic waste collection has a percentage impact determining on the quantity of unsorted waste product at the urban level (40\% of municipal waste is in fact composed by organic). In the Genoa case, to achieve the EU target on the recycling is therefore crucial to intercept the $52 \%$ of the organic waste product taking into account the share present in the undifferentiated urban waste and of the share collected through recycling. The increased of collection of organic waste therefore provides a two-year plan to reach all commercial and domestic utilities of the city.

Table 5: Example of description of action Urban Waste Management Plan.

\begin{tabular}{|l|l|}
\hline $\begin{array}{c}\text { OBJECTIVE } 2 \\
\text { Target of } 65 \% \text { of the } \\
\text { separate collection }\end{array}$ & \multicolumn{1}{c|}{$\begin{array}{c}\text { Action IV: Strengthening of organic waste } \\
\text { collection }\end{array}$} \\
\hline DESCRIPTION & $\begin{array}{l}\text { The organic waste collection: "door to door" for the } \\
\text { big producers (restaurants, canteens, markets...) and } \\
\text { of proximity to all households by 2016 }\end{array}$ \\
\hline PLACE OF INTERVENTION & The entire municipality \\
\hline INSTRUMENTS & $\begin{array}{l}\text { The placement of new bins on the street and in the } \\
\text { vicinity of several businesses. Hiring new staff } \\
\text { dedicated to the service of organic waste collecting }\end{array}$ \\
\hline STRAIGHT & $\begin{array}{l}\text { Assuming an interception rate between } 50-60 \% \text {, the } \\
\text { amount of organic waste collectible in a } \\
\text { differentiated manner is 55,000-65,000 t/year }\end{array}$ \\
\hline WEAKNESSES & $\begin{array}{l}\text { The lack of a center for the treatment of organic } \\
\text { waste }\end{array}$ \\
\hline SYNERGIES & With Amiu and Chamber of Commerce \\
\hline
\end{tabular}


The fourth phase involves the implementation and monitoring of the Plan. This phase will be based on a set of indicators evaluated ante and post implementation of the Plan (Table 6).

Table 6: Example of indicators of Urban Waste Management Plan.

\begin{tabular}{|c|l|c|c|}
\hline \multicolumn{1}{|c|}{$\begin{array}{c}\text { GENERAL } \\
\text { OBJECTIVES }\end{array}$} & \multicolumn{1}{|c|}{ INDICATORS } & $\begin{array}{c}\text { VALUE IN } \\
\mathbf{2 0 1 3}\end{array}$ & $\begin{array}{c}\text { VALUE IN } \\
\mathbf{2 0 1 8}\end{array}$ \\
\hline $\begin{array}{c}\text { 1. To encourage and } \\
\text { develop prevention }\end{array}$ & Urban solid waste production & $325.69 \mathrm{kt} / \mathrm{year}$ & $\begin{array}{c}\text { To be } \\
\text { defined }\end{array}$ \\
\hline $\begin{array}{l}\text { 2. Target of 65\% of the } \\
\text { separate collection }\end{array}$ & $\begin{array}{l}\text { Percentage of separate } \\
\text { collection }\end{array}$ & $34.3 \%$ & $65 \%$ \\
\hline \multirow{2}{*}{$\begin{array}{l}\text { 3. Target of 50\% of the } \\
\text { waste recovery to } \\
\text { 2020 }\end{array}$} & $\begin{array}{l}\text { Quantities intended to be } \\
\text { recovered (deriving by: } \\
\text { separate collection and } \\
\text { mechanical selection of } \\
\text { unsorted municipal waste) }\end{array}$ & $\begin{array}{c}60.66 \mathrm{t} \text { of steel, } \\
\text { aluminum, } \\
\text { paper, wood, } \\
\text { plastic and glass }\end{array}$ & $70 \%$ \\
\hline \multirow{2}{*}{$\begin{array}{l}\text { 4. To recover with } \\
\text { other techniques/ } \\
\text { technologies }\end{array}$} & Amount of energy obtained & $\begin{array}{c}66 \text { million } \\
\mathrm{kWh} / \mathrm{year} \\
\text { (biogas plant) }\end{array}$ & $\begin{array}{c}\text { To be } \\
\text { defined }\end{array}$ \\
\cline { 2 - 5 } & $\begin{array}{l}\text { Biodegradable municipal } \\
\text { waste sent to landfill }\end{array}$ & $\begin{array}{c}55,000 / 65,000 \\
\text { t/year }\end{array}$ & $\begin{array}{c}\text { To be } \\
\text { defined }\end{array}$ \\
\hline $\begin{array}{l}\text { 5. To achieve the } \\
\text { autonomy in the } \\
\text { undifferentiated } \\
\text { waste management }\end{array}$ & $\begin{array}{l}\text { Interventions for } \\
\text { commissioning rule and self- } \\
\text { sufficiency of the plants }\end{array}$ & No & $\begin{array}{c}\text { Adaptation } \\
\text { of plants }\end{array}$ \\
\hline
\end{tabular}

The last phase, awareness and participation actions of actors involved, is transverse to the other four and seeks the consensus and the collaboration also in operational terms. The awareness of the community to environmental issues is a key objective and necessary to the success of these new tools, the Waste Management Plans. Initiatives that are based on the information and awareness on separate collection, the art of recycling, the renewable energy, the consumer awareness... for citizens of all ages need to be developed.

The participatory approach also requires the active involvement of potential beneficiaries of a Plan in its different stages (since its conception). Thematic forums throughout the implementation of the Plan are important to organize already in the analysis phase (involving all actors from the institutional world, to that of research, to associations and businesses but especially the population). The participatory processes will play a key role in ensuring the full consent and cooperation between the actors involved and especially with the population that is the main actuator.

\section{Acknowledgements}

F. Pirlone - The author has coordinated in the project MED-3R the setting of the methodological approach aimed at defining guidelines for the preparation of the 
urban waste management Plan, reported in the paper, and she also illustrated the application to the case study Genoa.

I. Spadaro - The author has deepened the issue of waste at the European and Italian level (regulations, instruments...). In the project she has participated in the definition of the illustrated methodological approach, in particular revising the information of the partners involved, among which the GIZ experience.

\section{References}

[1] Directive 2008/98/EC of the European Parliament and of the Council of 19 November 2008.

[2] European Commission Directorate-General Environment "Preparing a Waste Management Plan. A methodological guidance note", 2012.

[3] Pirlone F., Spadaro I., "Towards a waste management Plan for smart cities", International Conference "The Sustainable City IX - Urban regeneration and sustainability", Marchettini N., Brebbia C.A., Pulselli R., Bastianoni S., (a cura di), WIT Press, UK, Volume II, ISBN 978-1-78466-024-6, 2014, pp. 1279-1290.

[4] Commissariat Général Au Développement Durable, Direction Generale De La Prevention Des RIsques, Service de l'Économie, de l'Évaluation et de l'Intégration du Développement Durable Lexique à l'usage des acteurs de la gestion des déchets, 2012.

[5] GIZ-ANGed PCGD Plan Communal de la Gestion des Déchets de la Commune de Sfax, 2013.

[6] Comune di Genova Piano di gestione rifiuti, 2014. 